\title{
26- Hitler türü propagandanın afişlerde kullanımı üzerine göstergebilimsel analiz
}

\section{Huri Deniz KARCI}

APA: Karcı, H. D. (2021). Hitler türü propagandanın afişlerde kullanımı üzerine göstergebilimsel analiz. RumeliDE Dil ve Edebiyat Araştırmalar Dergisi, (25), 415-428. DOI: 10.29000/rumelide.1039111.

Öz

Propaganda, belirli bir konu, görüş veya fikre yönelik ikna çabalarında ikna sınırlarını zorlayan bir alan olarak karşımıza çıkmaktadır. En yaygın biçimde görülen konu bakımından propaganda siyasal propaganda olarak gösterilebilmektedir. Hitler türü siyasal propaganda en sık başvurulan propaganda türlerindendir. Bu çalışma, Hitler türü siyasal propagandanın bir iletişim aracı olarak afişlerde ne şekilde uygulandığını betimlemek amacındadır. Sembolik iletişimi güçlü şekilde kullanan bu propaganda türü göstergebilimsel analiz yöntemiyle incelenmiştir. İki adet Hitler propaganda afişi, göstergebilim öncülerinden Roland Barthes' ın düz anlam ve yan anlam yaklaşımı baz alınarak deşifre edilmiştir. Afişlerde, göstergelerin taşıdıkları anlamların yanı sıra propaganda kurallarına ne şekilde uyulduğu da sorgulanmıştır. Hitler türü propaganda, geçmişten bugüne farklı mecralarda çeşitli göstergebilimsel, içerik ve söylem analizlerine konu olmuştur. Görsel açıdan etkisi yüksek iletişim mecralarından biri olan afişlerde Hitler türü propaganda incelenerek Roland Barthes'in ortaya koyduğu anlamsal analize tabi tutulmuştur. Bu anlamsal çözümlemenin alana katkı sağlayacağı düşünülmektedir.

Anahtar kelimeler: Hitler türü propaganda, göstergebilim, düz anlam, yan anlam

\section{A semiological analysis on the use of Hitler propaganda in posters}

\begin{abstract}
Propaganda occurs as a field which enforces persuasion limits in persuasion efforts towards a certain issue, view or idea. The most common propaganda type in terms of topic could be political propaganda. Hitler propaganda is one of the most frequently applied propaganda types. The study aims to define in what way Hitler propaganda is applied in posters as a communication medium. This type of propaganda, which employs symbolic communication vigorously, was analyzed through semiotics. Two posters of Hitler propaganda was deciphered depending on Roland Barthes's - one of the pioneers in semiotics- denotation and connotation approach. Apart from the meanings carried on the signs, how was obeyed propaganda rules in posters was questioned. The analysis of Hitler propaganda, which has been practised in different areas from past to present, is thought to contribute to the field in terms of a detailed analysis in posters as an artistic medium.
\end{abstract}

Keywords: Hitler propaganda, semiotics, denotation, connotation

Dr. Öğr. Üyesi, Ankara Medipol Üniversitesi, İletişim Fakültesi, Halkla İlişkiler ve Reklamcılık (Ankara, Türkiye), huri.karci@ankaramedipol.edu.tr, ORCID ID: oooo-0oo3-1544-8249 [Araştırma makalesi, Makale kayıt tarihi: 20.11.2021-kabul tarihi: 20.12.2021; DOI: 10.2900o/rumelide.1039111]

Adres | Address

RumeliDE Dil ve Edebiyat Araşturmaları Dergisi Osmanağa Mahallesi, Mürver Çiçeği Sokak, No:14/8 Kadıköy - İSTANBUL / TÜRKIYE 34714 e-posta: editor@rumelide.com

RumeliDE Journal of Language and Literature Studies Osmanağa Mahallesi, Mürver Çiçeği Sokak, No:14/8

Kadıköy - ISTANBUL / TURKEY 34714 tel: +90 $5057958124,+902167730616$

e-mail: editor@rumelide.com

phone: +90 505 7958124, +90 2167730616 


\section{Giriș}

\section{Propaganda}

Yıllardır süregelen tartışmalı bir kavram olarak "propaganda" üzerine birçok tanım yapılmaktadır. Domenach (1995) propaganda kavramını etki altına alınmak istenen toplumun güdülenmesine yönelik bir aksiyon olarak tanımlamaktadır. Ona göre bir yandan propaganda kitlelere yönlendirilmiş bir dildir. Bunun için radyo, basın, sinema yoluyla kitleye ulaştırılan sözler bir araç ve simge olarak kullanılmaktadır. Özsoy (1998: 5), propagandayı "bireyler ve gruplar aracılı̆̆ıyla diğer grupların kanılarını, görüşlerini ve davranışlarını, iletişim araçlarını kullanarak, propagandacının istekleri doğrultusunda etkileme, değiştirme ya da kontrol altında tutmaya yönelik bilinçli bir davranış” olarak görmektedir. Laswell, insan davranışlarının çeşitli iletişim araçlarının kullanılmasıyla etkilenebileceğini ve sözler, yazılar, resimler ve müzik kullanılarak bunun gerçekleştirilmesini propaganda olarak tanımlamaktadır (Kalender, 2005: 79). Bektaş (2002:31), daha detaylı bir yaklaşım ile propagandayı ele almaktadır. Ona göre, propaganda simgeler kullanılarak halkın bazen gerçek, bazen yarı gerçek ve bazen de gerçek olmayan bilgilerin yayılmasıyla etki altına alınması ve bu yolla yalnızca bireylerin değil grup ve toplulukların da inanç, tutum veya eylemlerinin yönlendirildiği bir gayrettir. Brown (1992: 11), Siyasal Propaganda adlı eserinde Oxford sözlüğünün yaptığı propaganda tanımına yer vermektedir: "Bir doktrin ya da uygulamayı yaymak için desteklemek ya da tasavvurda bulunmak". Brown, Latince "propagare" kelime kökenine dayanan propagandanın tıpkı bir bahçevanın bitki ekip yetiştirmesindeki gibi bir tavır mantığından geldiğinin altını çizmektedir. Ona göre propaganda sözcüğünün günümüzdeki tanımı sık sık, iyi karşılanmayan ya da kabul edilemez bir bilgiyi kötü niyetli bir kişinin faaliyetlerine işaret eden 'beyin yıkama' deyimiyle eş anlamlı olarak kullanılmaktadır. Leonard W. Doob ise, Kamuoyu ve Propaganda isimli eserinde propaganda tanımını şu şekilde yapmaktadır: "İlgili kişi (ya da kişilerin) telkin vasıtasıyla grupların tutumlarını ve sonuçta da bu grupların hareketlerini kontrolleri altına almak için yaptıkları sistematik faaliyetlerdir (aktaran Brown, 1992: 23). Literatürde görülen "propaganda" tanımlarına bakıldığında; göndericinin, hedef aldığı alıcı üzerinde oluşturacağı etki ile onda bir davranış değişikliği yaratma amacında olduğu görülmektedir. Bu amaç doğrultusunda, alıcıya seçme şansını sunmadan mesajlarını bilinçaltına ekerek bir manipülasyon sürecine girdiği söylenebilir. Bu anlamda; propagandanın, hangi alanda yapılırsa yapılsın o alana özgü etik anlayışına temelde uymadığı dikkat çekmektedir. Başarı yolunda her yolu mübah gören bir anlayış dikkat çekmektedir. Hedefe kitlenen propaganda uygulayıcısı, iletilerini çeşitli anlamlarla yükleyerek bir çeşit kodlama paketi oluşturmaktadır. Bu sebeple; propaganda sürecinde kodlanan iletilerin yapısal olarak dikkatle çözümlenmesi gerekir.

Propagandanın kişilerin, toplulukların düşüncelerini kendi isteği yönünde değiştirmek, kontrol altına tutmak gibi bir gayede olduğu söylenebilir. Kalender (2005: 79) temel düzeyde propaganda amacının "kişileri veya grupları çeşitli tekniklerle etkilemek" olduğunu belirtmektedir. Domenach (1995), propagandanın amacının politik düşüngü ve reklâm olmak üzere iki ana kaynağa dayalı olduğunu ifade etmektedir. Bektaş ise(2002: 159), propagandanın amacına daha geniş bir perspektiften yaklaşır. Ona göre propaganda, kendisi üzerine amaçlanan bireyleri yalnızca bir öğretiyi benimsetmeye çalışmaz; onları bu süreçte aktif bir şekilde yönetmek ister. Bu çerçevede sözünü ettiği propaganda daha ziyade siyasal alanda gelişmektedir.

Etkin bir propagandanın gerçekleştirilebilmesi, amacına ulaşabilmesi için bilinçli, sistematik bir yol izlenmesi gerektiği bilinmektedir. Bu sebeple propagandanın amacına yönelik tekniği ve aracı

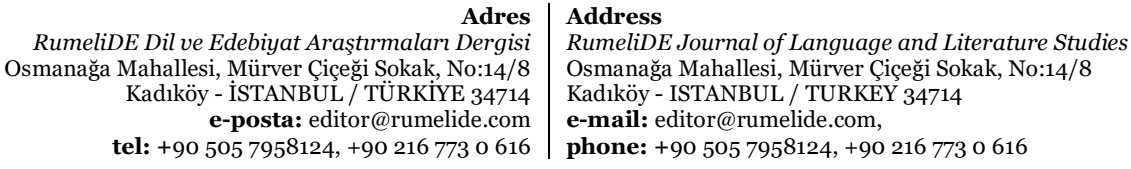


belirlemesi gerekmektedir. Özsoy (1998: 92), tüm kuramcıların genel olarak hemfikir olduğu beş propaganda kuralından bahsetmektedir. Buna göre kurallar şu şekilde çeşitlenmektedir:

1.Konuları sadeleştirme ve teke indirme kuralı: Propaganda amacına ulaşmak için kafa karıştırıcı olmamalıdır. Belirli bir düşünce etrafında kamuoyu toplanmak istendiği için savunulan fikir kısa ve sade bir şekilde sunulmalıdır.

2.Birlik ve bulaştırma kuralı: Amacı gereği propaganda, isteği yönünde kamuoyu oluşturmak hedefindedir. Savunduğu düşünceyi etkin kılmak için ve derin bir etki yaratmak için herkesi belli bir fikrin etrafında toplar. Öte yandan bu etrafında birleşilen fikir toplumda olabildiğince çok kişiye ulaştırılmalıdır. Bir bakıma kişiden kişiye bulaştırılmalıdır. Bayraklar, semboller, amblemler, sancaklar, yazılar gibi çeşitli araçlarla tek bir fikir yaratma eylemi pekiştireç olarak kullanılır. Mitingler ve yürüyüşlerle birleşilen fikir kişiden kişiye bulaştırılır.

3.Büyültme, şişirme kural: Kamuoyu oluşturulmak istenen konu hakkında gündem yaratılarak, haberler çıkartılarak işe yarayacak bölümler öne çıkartılmaktadır. Hatta konu ile ilgili abartılı durumlar yaratma ilgi çekici olacaktır.

4.Tekrarlama kuralı: Teke indirilen ve sadeleştirilen fikir sık tekrarla zihinlere kazınmaya çalışılır.

5.Geçiş evresi kurah: Yeni gelişen bir fikir kabul ettirilmek isteniyorsa, halkın aşina olmadığı bir konuya yavaş yavaş ve dikkatle işlemek gerekmektedir.

Lerner (2000: 271), propagandanın etkin biçimde nihayete erebilmesinin özellikle şu dört şarta bağlı olduğu görüşündedir:

1.Kitlelerin dikkati sağlanmalıdır: Öncelikle çeşitli gündem ve haberlerle kitlelerin dikkati benimsetmek istenilen fikir, düşünce veya konuya çekilmelidir.

2.Kitlelerin güveni kazanılmalıdır: İletişimin alıcı konumundaki kitlelerin hedeflenen fikir, düşünce veya konuya ısındırılması ve inandırılması için propaganda uygulayan kaynağın güvenilir olması gerekmektedir.

3.Tutum ve davranışlarının değiştirilmesi hedeflenen alternatifler hoş görünecek şekilde sunulmalıdır: O güne kadar hedef kitlede kemikleşmiş düşünce, tutum, güdülerin varlı̆̆ı öncelikle göz önünde bulundurulmalıdır. Yerine konmak istenen karşıtlarıysa çekici gösterilmelidir.

4.Kitleler harekete geçirilmelidir: Aşama aşama gelinen bu noktada inandırılabilmiş olan kitle harekete geçirildiği taktirde propaganda amacına ulaşabilmektedir.

Brown (1992) ise daha çok savaş propagandası yönünden teknikleri ele almaktadır. Propagandacının görevlerinin dinleyicisinin dikkatini konuya çekmek, dinleyicilerin hali hazır doğalarında var olan kodları uyandırmak ve bunun için sıklıkla duygulara başvurmak olduğunu dile getirmektedir. Bu dikkat çekme ve uyandırma girişimlerinde telkin yöntemine başvurma gereğinin altını çizmektedir. Telkin etmek içinse en uygun dinleyici kitlesinin çocuklar ve gençlerden oluştuğunu çünkü bunun için en uygun grubun onlar olduğunu savunmaktadır. Ona göre propaganda için şu tekniklerin kullanılmasında fayda vardir:

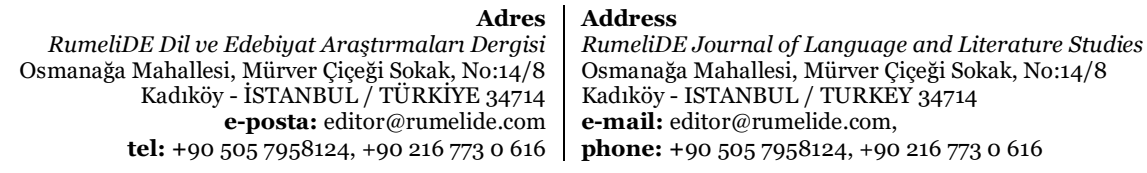


1. Kahplaşmış imajların kullanılışı: İnsanları belirli sınıflamalara tabi tutmak yaygın bir durumdur. Fakir, zengin, işçi, yaşlı, genç, Yahudi, yönetici gibi etiketler onların gerçek durumlarının düşünülmesinden uzaklaştırır. Bu kalıplaşmış imajlar istenilen yönde düşünce yaratmak için elverişlidir.

2. İsimleri bir başka lakapla değiştirme: Propaganda yapan kişi veya kişiler, karşıt veya hemfikir oldukları kişilere birtakım lakaplar yerleştirerek belirli duygular uyandırırlar.

3. Seçme: Propaganda yapan kişi veya kişiler, sansürleme gibi çeşitli tekniklerle karmaşık veya yığın halindeki durumlardan işine yarayanları seçmektedir. Böylelikle hedef kitlenin dikkatini çekmek ve bir yere odaklamak daha uygun olacaktır.

4. Tümüyle Yalan: Propaganda yapan kişi veya kişiler istemedikleri fikirleri kolaylıkla yalanlayabilmektedirler.

5. Tekrar: Tekrar, öğrenmenin en önemli etmenlerinden biridir. Hedeflenen düşünce, eylem veya konuya yönelik tekrar onun benimsenmesinde kolaylık sağlayacktır.

6. İddia: Propaganda yapan kişi veya kişiler tartışmalara girmekten ziyade kendi yönünde olumlu imaj yaratacak noktalara temas etmelidir. Bu anlamda olumlu iddialar ortaya atmak etkili olacaktır.

7. Düşmanın Tanımlanması: Her ne kadar tartışmalara girmese de propaganda yapan kişi veya kişilerin karşısında duranların kim olduğu hedef kitleye örtük veya açık şekilde gösterilmelidir. Böylelikle kitle, kime yaklaşıp kimden uzak kalması gerektiğine dair telkin edilmiş olacaktır.

8. Otoritenin Teyidine Siğınma: Hedeflenen konuda otorite olarak görülen, uzman kişi veya çoğunluğa atıfta bulunmak etkiyi artıracaktır. "Tüm dünyada olduğu gibi..” gibi ifadeler iknayı kolaylaştıracaktır.

Propaganda sıklıkla ve etkili biçimde siyaset alanında kullanılsa da pek çok farklı alanda başvurulmaktadır: Propagandanın kapsamı bakımından genel, sınırlı veya kişisel propaganda türlerine başvurulmaktadır. Uygulanacağı konu bakımında en yaygın olarak siyasal, ekonomik, kültürel ve askeri propaganda türleri dikkat çekmektedir. Uygulandığı saha bakımından iç ve dış propaganda mevcuttur. Uygulanacağı yöntem bakımından beyaz veya açık, gri veya bulanık ve kara veya sinsi propaganda türleri geliştirilmektedir. Bunların dışındaysa toplumsal, dikey ve yatay, akılcı ve duygusal, karıştırıcı ve bütünleştirici propaganda türleri de kullanılmaktadır (Eke, 2008: 60-70).

\section{Siyasal propaganda}

Siyaset arenasının propagandaya en sık başvurulan alanlardan olduğu söylenebilir. Siyasi liderler ya da kurumlar halkın oylarını kazanmak, onları kontrol altında tutmak adına propaganda yapabilmektedirler. Özsoy (1998:91), siyasal propagandayı seçim dönemlerinde oy tercihlerini etkilemeyi tasarlayan ikna edici bir iletişim biçimi olarak görmektedir. Kalender (2005: 126-131), siyasal propagandada iknanın önemi üzerinde durmakta ve burada seçmenlerin ikna edilmesi hususunda şu tekniklere dikkat çekmektedir: "korku çekiciliŭi”, "kapıyı aralama tekniği” ve "mesaj tekrarı". "Korku çekiciliği” tekniğiyle insanlar, kabul ettirilmek istenen eylemin karşıtını gerçekleştirirlerse çeşitli zararlar ve tehditler oluşabileceğine inandırılmaktadırlar. Özellikle siyasal propagandada başvurulan korku çekiciliğiyle propagandacı seçimde kaybetmeleri durumunda ülkenin kötüye gideceği, birlik ve beraberliğin bozulacağı gibi mesajlar verilmektedir. Fakat burada propagandacının güvenilir bir zat

\footnotetext{
Adres $\mid$ Address

RumeliDE Dil ve Edebiyat Araştırmaları Dergisi $\quad$ RumeliDE Journal of Language and Literature Studies Osmanağa Mahallesi, Mürver Çiçeği Sokak, No:14/8 Osmanağa Mahallesi, Mürver Çiçeği Sokak, No:14/8 Kadıköy - ÍSTANBUL / TÜRKIYE 34714 Kadıköy - ISTANBUL / TURKEY 34714 e-posta: editor@rumelide.com e-mail: editor@rumelide.com, tel: +90 505 7958124, +90 2167730616 phone: +90 505 7958124, +90 2167730616
} 
olması etki açısından önem arz etmektedir. "Kapıyı aralama tekniği” uygulayan propagandacılar dinleyicilerine razı ettirme psikolojisi uygulamaktadırlar. Şimdi razı olacakları bu durum sayesinde dinleyiciler ileride kazançlı çıkacaklarına inandırılmaktadırlar. Son olarak "mesaj tekrarı" da sıklıkla siyasal propaganda tekniği olarak uygulanmaktadır. Birtakım seçilmiş ifadeler sık sık tekrarlanarak zihinlere kazınmaya çalışılmaktadır.

\section{Siyasal propaganda türü olarak Hitler (Nazi) propagandası}

Hitler, propagandayı yapılan genel tanımlara paralel olarak telkin, ikna stratejileri gibi teknikleri profesyonelce kullanarak yürütmüştür. Belki de başarılı propaganda süreci propagandayı bir "sanat" olarak görmesine bağlanabilir. Sanat olarak gördüğü propaganda için "propaganda bir vasıtadır, bunun için amacı yönünden hakkın-bir yargıya varılmalıdı” diye söz etmektedir ( Hitler, 2011: 147-154). Bu görüşüne şöyle devam etmektedir: "Propaganda savaş sırasında, bir amaca ulaşmak için kullanılan vasıtaydı... Propaganda daha seri bir zaferin şartıydı ve millete; hürriyet, şeref ve haysiyetini sağlamasına yardım ediyordu. Yaşamak için yapılan bu mücadelede "savaş propagandası" hakkında aldığım vaziyet buydu.” Bu noktada Almanya'da kendinden önce sürdürülmüş propagandanın başarılı olamayışını açıklamak üzere şu sözlerle devam etmektedir: "Hükümetçe bu husus açıkça anlaşılmış olsaydı, bu silahı kullanmanın şekli hakkında hiçbir zamana tereddüde düşülmeyecekti. Çünkü kullanmasını bilenin elinde, bu silah gerçekten korkunç ve dehşet verici bir şey olurdu." Hitler' in propagandada önemli bulduğu bir başka nokta ise propagandanın kime hitap ettiğinin bilincinde olma gereğidir. Propaganda aydınlara mı yoksa halkın az öğrenim görmüş bir kitlesine mi? Kendi sorusuna burada çoğunlukla bir topluluğa hitap etme gereği ile cevap vermektedir. Öte yandan propagandanın amacının kitlelerin dikkatini belirli olaylara çekmek olduğunu ve bunun içinde "seçme" tekniğinin kullanılması gerektiğini savunmaktadır. Bir başka önem verdiği teknikse "tekrar”dır.

Brown (1992: 56-61), Hitler türü propagandanın savaş dönemi Almanya'sında etkili oluş nedenlerini açılarken hastalıklı bir toplumun hastalıklı bir liderle örtüşmesi noktasına Alex Comfort'un Authority and Delinquency inthe Modern State isimli eserinde göstermiş olduğu iktidar sevgisi ve kusurun yakın ilişkisi açısından ışık tutmaktadır. Nazi döneminde Almanya'yı yönetenler kendi kişisel özellikleriyle politikaya girmişlerdir. Hitler de kendi mevcut zayıf yanlarından yola çıkarak kendisini topluma empoze etmeye çalışmıştır. Hitler, Alman değil bir Avusturyalıydı ve işçi sınıfından gelmemekteydi ama mütevazı bir aile kökenine sahipti. Öfkeli bir askerdi, histerik ve paranoyak tutumları bulunmaktaydı ve başarılara pek de imza atamamış bir sanatçıydı. Hitler, doğası gereği Almanların o anda içinde bulundukları psikoloji için uygun bir zattı. Problemleri pratik bir şekilde çözmeye en uygun kişi olmasa da kendi duygularıyla o anı en iyi yansıtan kişiydi. Hasta bir grubunsa hasta bir lider seçmesi olağan bir durumdu. Hayal kırıklı̆ı içindeki kişiler nefret etme eğilimindedirler. Çünkü nefret, başkalarıyla paylaşıldıkça en güçlü birleştirici duygu olabilmektedir. Bunların değerini anlayan Hitler, propagandasını bu dinamiklere dayandırmaktaydı.

Kongar (http://www.kongar.org/makaleler/mak_na.php), Hitler propagandasının kullandığı araçlardan söz ederken kitle iletişim araçlarına dikkat çekmektedir. Burada siyasal ve toplumsal propagandada beyin yıkama amacının varlığından bahsetmekte ve bunun için Naziler' in sıklıkla radyo kitle iletişim aracını kullandıklarını anlatmaktadır. Hitler türü propagandada sevgi, öfke, nefret, tutku gibi duyguların yoğunluğunun hedef kitlenin ikna edilebilirliği açısından önemli görülmektedir. Bu noktada Domenach (1961: 43), Hitler'in halkı kadına benzetmesi konusu üzerinde durmaktadır. Hitler' göre, duygusal yönü ağır basan kadınlar gibi halkın çoğunluğunun çeşitli zaafları bulunmaktadır ve kararlarını muhakeme güçleriyle değil çoğunlukla hisleriyle vermektedirler.

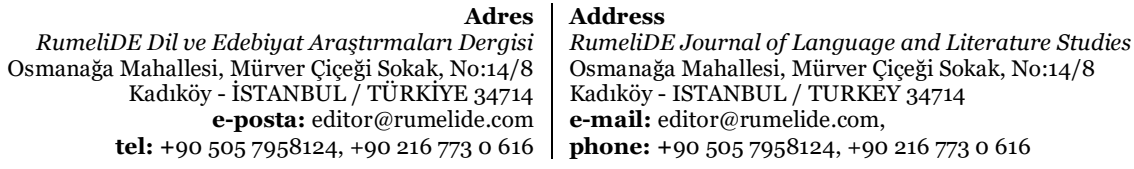


Hitler propagandasının önde gelen uygulayıcılarından biri olan Goebbels de iktidara gelmelerinin en büyük araçlarından birinin propaganda olduğunu söylemektedir. Hitler gibi o da modern propagandayı bir sanat olarak görmektedir. Başarılı bir propagandayı direkt olarak istenilen sonuca ulaşmakla bağdaştırmaktadır. Tüm resmi ajansları, basın, radyoyu, vb. propaganda aracı olarak kullanmaktadırlar. Alman haber ajanslarını tek bir ajansa -DNB- bağlayarak propaganda için verimli bir şekilde basını Nazi propagandası, maddi umutlar yerine ari bir kültürü temel alan bir dünya görüşünü vaad etmektedir. Ona göre, kitleler bu ırkçı politikayla harekete geçirilmektedir (Yılmaz, 2007: 71-72).

\section{Göstergebilim}

İletişimin temeli olan dile yapısalcı bir yaklaşım üzerinden bakan göstergebilim, dilin içerisindeki her bir görsel ve işitsel sembol, işaret ve ikonların önce parçalara ayrılarak sonra bütüncül bir halde ele alınması gerektiğini savunmaktadır. İletişimin bir anlam üretim alanı olduğu düşüncesinden yola çıkan göstergebilimde her bir ileti anlam yüklü bir metni esil etmektedir. Bu anlamda bu metni okumak için yapısal özellikleri iyi tanımak gerekmektedir. Göstergebilim, iletişim sürecini başlatan kaynağın iletiyi kodlama eylemi sırasında yüklediği anlamları görünen ve altında yatan anlamlarıyla çözümlemeyi mümkün kılan bir bilim dalıdır.

İlk defa 17. yüzyllda John Locke tarafından An Essay Concerning Human Understanding (1690) adlı eserinde "semiotike"-"göstergeler öğretisi” olarak terime değinilmiştir. Zamanla incelenmeye başlanan bu terim dilbilimsel olarak yeni bir çalışma alanı haline gelmiş ve Avrupa'da Ferdinand de Saussure, A.B.D.'de ise Charles S. Peirce öncülüğünde bağımsız bir bilim dalı olarak ayrılmıştır (Teker, 2003).

Göstergebilimin İsviçreli öncüsü Ferdinand de Saussure (1983), göstergebilimi bir göstergeler sistem, içerisinde bireysel ve grup ilişkileri içerisinde buluna göstergeler ve semboller bilimi olarak görmektedir. Buna göre göstergebilim anlamın nasıl yapılandırıldığını ve anlaşıldığını çalışan bilim dalıdır. Saussure, bu anlam taşıma sürecinin birtakım kodların kullanımın dayandığını ifade etmektedir. Bu kodlar, insanların sözcükler oluşturmak için kullandıkları ayrı birer ses veya harf olabildikleri gibi, tavırlarını ve duygularını göstermek için kullandıkları jest ve mimikler ve hatta giydikleri her bir kıyafet parçası dahi olabilmektedir. Toplum tarafından anlamı üzerinde uzlaşılan bir kod dilin bir öğesi olabildiği gibi kültürel değerleri de ifade edebilmektedir. Bu açıdan F. de Saussure, göstergebilimi 'göstergelerin toplum içindeki yaşamını inceleyecek bilim’ olarak tasarlamaktadır (Aktaran: Guirad, 1990: 17-20). Saussure, bu anlamda göstergebilime dilin kökeninde yatan her türlü görsel, işitsel kodların toplumsal açıdan yüklenen anlamlarıyla yaklaşmaktadır.

A.B.D’li göstergebilim öncüsü Charles S. Peirce ise, Saussure'un dilbilimsel ve toplumsal göstergebilim anlayışının aksine daha mantıkçı bir çerçeveden bakmaktadır. Bu sebeple dilbilimi göstergebilimin bir alt dalı olarak görmektedir. Peirce, göstergebilimi bir genel göstergeler bilimi olarak işaret etmektedir (Teker, 2003). Göstergebilimi göstergeler üzerine genel bir kuram olarak tasarlayan Peirce birebir "mantık" sözcüğünü göstergebilim yerine kullanacak kadar anlamdaş görmektedir. Bu anlamda ona göre göstergebilim, göstergelerin gerekli ve biçimsel bir öğretisidir (Guirad, 1990: 17-20).

Roland Barthes ise göstergebilimi şu şekilde tanımlamaktadır "Göstergebilim bir serüvendir... Gösterenden bana gelen şeydir.” (Barthes, 1993: 12). Görüntüler, el-kol baş hareketleri, ezgili sesler, nesneler, vb. her kodu birer gösterge dizisi olarak ifade etmektedir. Peirce’in aksine o göstergebilimi, dilbilimin bir bölümü olarak görmektedir. 1965'te yayımlanan eseri Elements of Semiology ile Saussure'un göstergebilimsel fikrini dile getirmiştir.

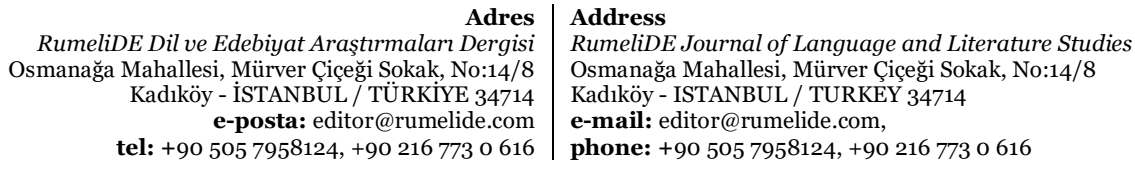


Pierre Guiraud (1990: 17), "Göstergebilim, diller, düzgüler, belirtgeler, vb. gibi gösterge dizelerini inceleyen bilimdir... Bu da göstergebilimi 'dilsel olmayan göstergelerin incelenmesi' biçiminde tanımlamaya olanak vermektedir.” Diyerek dilbilimle sınırlanmasından uzak tutmaktadır.

\section{Göstergebilim terimleri}

\section{Gösterge}

Saussure, göstergebilimin göstergelere anlam yükleme işi olduğunu dile getirirken bir yandan da toplumda var olan göstergelerin sosyal psikoloji ve genel olarak psikoloji bilim dalıyla iç içe çalışılması gerektiğini ifade etmektedir. Bu açıdan dil yapı taşları olan kodların göstergelerle eş olduğunu birr göstergeninse tek başına var olmadığını "gösteren" ve "gösterilen”in birbirlerinden bağımsız var olmaları ve birbirleriyle iç içe geçmiş anlam bütünlüğüne bağlı olduğu savını ortaya koymaktadır. Bu anlamda Saussure’a göre dilsel "gösterge" iki taraflı psikolojik bir varlıktır: "kavram" ve "işitsel imge".

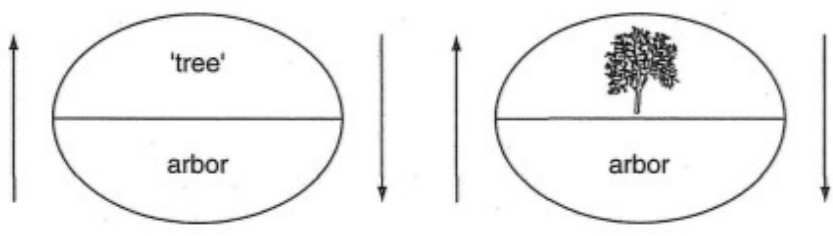

F. de Saussure’un Gösterge, Gösteren, Gösterilen Modeli

Kaynak: Saussure, de F. (2004).

Saussure, bu gösterge modellemesiyle "ağaç" işitsel imgesi ile zihnimizde oluşan kavramı özdeşleştirmiştir. Her ikisi de birbirine çağrışım yapmaktadır. Bu sebeple gösterge bu iki varlığın bir araya gelişidir. Kelime olan "ağaç”a ait harfler (kodlar) kasıtsız bir şekilde bir araya gelmiş ve zihnimize bildiğimiz bu görsel kavramı temsil etmiştir. Bu sebeple gösterge, gösteren ve gösterilenin kasıtsız gelişmiş bağı ile oluşmuştur.

Barthes 1957'de yayımladığı Mythologies adlı eserinde gösterge, gösteren ve gösterilen ilişkisini incelemektedir. Ona göre dil bir “mit”tir ve gösterge, gösteren, gösterilenden oluşan üç boyutlu bir desen sahiptir. Bu desene göre; gösterge kavram ve imgenin çağrışımsal bir toplamıdır. Bu öğeler, bir mitsel konuşma olan dilin parçalarıdır. Bu mitsel konuşma dilin kendisi olabildiği gibi fotoğraf, tablo, afiş, ritüel, obje, vb. her şey olabilir. Hepsi bize bit mit anlatmaktadır:

Language
MYTH $\left\{\left\{\begin{array}{|r|r|}\hline \multicolumn{1}{|c|}{\begin{array}{l}\text { 1. Signifier } \\ \text { 3. Sign I } \\ \text { SIGNIFIER }\end{array}} & \text { II SIGNIFIED } \\ \hline \multicolumn{2}{|c|}{\text { III SIGN }} \\ \hline\end{array}\right.\right.$

Rolan Barthes'n Gösterge, Gösteren, Gösterilen Modeli

Kaynak: Barthes, 2004.

Barthes (2004), mit olarak gördüğü her türlü görsel, işitsel, yazınsal anlatıda gösteren ve gösterilenden gelişen "gösterge"yi aynı zamanda ayrı bir gösterilenle tamamlanan yeni bir gösterge olarak görür ve bu

\footnotetext{
RumeliDE Dil ve Edebiyat Araşttrmaları Dergisi RumeliDE Dil ve Edebiyat Araştırmaları Dergisi
Osmanağa Mahallesi, Mürver Ciçeği Sokak, No:14/8 Kadıköy - İSTANBUL / TÜRKIYE 34714 e-posta: editor@rumelide.com tel: +90 $5057958124,+902167730616$

Address

RumeliDE Journal of Language and Literature Studies Osmanağa Mahallesi, Mürver Çiçeği Sokak, No:14/8

Kadıköy - ISTANBUL / TURKEY 34714

e-mail: editor@rumelide.com,

phone: +90 505 7958124, +90 2167730616
} 
birleşim de yeni bir göstergeyi getirecektir. Anlatılan miti iç içe geçmiş göstergelerden oluşmuş bir bütün olarak resmetmektedir. Bu iki aşamalı süreçte bir düz anlam (denotation) bir de yan anlam (connotation) bulunmaktadır. Düz anlam, göstergenin olduğu gibi kavrandığı halidir. Yan anlamsa düz anlamın dışında ondan etkilenerek ortaya çıkmış yeni göstergesel ilişkidir. İletişimdeki alıcının iletiden çıkarttığı altta yatan anlamlardır.

Peirce'in temel anlamda Saussure'unkine benzeyen modellemesinde ise temel, nesne ve yorumlayan bulunmaktadır. Ona göre gösterge, herkes tarafından uzlaşılmış evrensel bir anlama sahiptir. Gösterge olmadan hiçbir iletişim sürecinin var olamayacağını söylemektedir. Saussure'un aksine dil dışı nesneleri de göstergebilime dahil etmektedir (Mazıcı, 2018). Peirce’a göre gösterge üç türlüdür: ikon, belirti ve sembol. İkon, görüntü göstergesidir. Nesne ile arasında bağı olan göstergeden bahseder. Belirti, nesnesi ile olan bağa yine mecbur olan aksi taktirde anlamı gelişemeyecek fakat bunu yorumlayan yoksa anlamını koruyan göstergedir. Sembol ise, kendisini yorumlayan olmaması durumunda gösterge olma özelliği kaybolandır (Alyakurt, 2017).

Gösteren (ses imgesi): Gösterme eylemini gerçekleştiren herhangi bir materyal, örneğin; bir sayfadaki sözcükler, bir yüz ifadesi, bir imge. Saussure'e göre; Göstergenin duyulan yani ses imgesidir. Akla ilk gelen görüntüsüdür (1983: 578) Barthes'a göre; gösterilenden tek ayrımı gösterenin bir aracı olmasidir (1993: 46).

Gösterilen (kavram): Gösterenin anlattığı kavramdır. Göstergenin ilk bakışta görülen somut halinden ziyade, çağrıştırdığı kavramlar bütünüdür denebilmektedir. Barthes'a göre; gösterilene ilişkin tartışmaların ruhbilimin izlerini taşımaktadır: Gösterilenin, göstergeyi kullananın bundan anladığı “şey” dir (1993: 43). Saussure (1983: 650) gösterilenin öz niteliğini, kavram terimini kullanarak iyi belirtmiştir: “Öküz sözcüğünün gösterileni, hayvanın kendisi değil, onun zihinsel imgesidir.

\section{Araştırma yöntemi}

Bu çalışma, Hitler türü siyasal propagandanın uygulandı̆̆ı iki adet afişin göstergebilimsel analiz yöntemi ile incelenmesi üzerine betimsel bir çalışma olarak gerçekleştirilmiştir. Burada göstergebilimsel analiz Roland Barthes'ın gösteren, gösterilen ve gösterge kavramlarına getirdiği düz ve yan anlam perspektifiyle gerçekleştirilmiştir. Gösteren ve gösterilen toplamı olan göstergelerde kavramsal çerçevede bahsi geçen Hitler türü propaganda tekniklerinin özellikleri sorgulanmıştır.

\section{Araştırma problemi ve amacı}

Hitler türü propaganda, siyasal propaganda türleri içerisinde geçmişten bugüne hem siyasal propaganda kapsamında hem de toplumsal ve yönetimsel pek çok alanda etkisi kanıtlanmış bir propaganda uygulaması olmuştur. Propaganda uygulama kurallarını titizlikle uyan bu türün dünyanın her yerinde farklı alanlarda uygulanışı detaylı bir inceleme gereği uyandırmıştır. Bu çerçevede, bu çalışma Hitler türü propagandanın Hitler' in de sanat olarak gördüğü propagandanın özellikle sanatsal izler taşıyan afişlerinde uygulanışını ve belirli kurallara nasıl uyduğunu betimlemek amacındadır.

\section{Araştırma sorusu ve alt problemler}

Çalışmanın amacı doğrultusunda "Hitler türü propagandanın kural ve tekniklerinin afişlerde ne şekilde işlendiği” sorusuna cevap aranmaktadır. Roland Barthes'ın göstergebilimsel yaklaşımına dayanılarak incelenmek istenen afişler için alt problemler şu şekilde geliştirilmiştir:

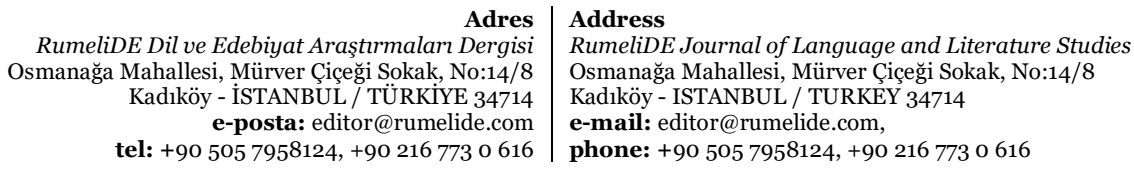


1.Hitler türü propagandanın yansıdı̆̆ı afişlerde göstergelerin düz anlamları nelerdir?

2.Hitler türü propagandanın yansıdığı afişlerde göstergelerin yan anlamları nelerdir?

\section{Evren ve örneklem}

Siyasal propaganda türünü uygulayan pek çok dünya lideri mevcuttur. Çalışma kapsamında Adolf Hitler'in uyguladığı propaganda türü incelenmek istendiğinden amaçlı örneklem uygulanmıştır. Adolf Hitler'in uyguladığı propaganda türü pek çok farklı mecralarda incelenmiş olduğundan, kendisinin sanat olarak gördüğü propaganda tekniklerini sanatsal olan afişlerde incelemek uygun görülmüştür. Bu bakımdan tekniklerin dikkat çektiği iki adet afiş uygun örneklemle indirgenmiştir.

\section{Veri analizi}

İncelenen afişler Roland Barthes'ın göstergebilimsel yaklaşımında temel olan düz anlam ve yan anlam kapsamında göstergebilimsel analiz ile incelenmiştir.

\section{Göstergebilimsel çözümleme çerçevesinde bulgular}

\section{1.“Çocuklar, Führer hakkında ne biliyorsunuz?” Afiş̧i}

Barthes 1957'de yayımladı̆̆ Mythologies adlı eserinde gösterger, gösteren ve gösterilen ilişkisini incelemektedir. Ona göre dil bir “mit"tir ve gösterge, gösteren, gösterilenden oluşan üç boyutlu bir desen sahiptir. Bu desene göre; gösterge kavram ve imgenin çağrışımsal bir toplamıdır. Bu öğeler, bir mitsel konuşma olan dilin parçalarıdır. Bu mitsel konuşma dilin kendisi olabildiği gibi fotoğraf, tablo, afiş, ritüel, obje, vb. her şey olabilir. Hepsi bize bit mit anlatmaktadır

Barthes (2004), mit olarak gördüğ̈̈ her türlü görsel, işitsel, yazınsal anlatıda gösteren ve gösterilenden gelişen "gösterge"yi aynı zamanda ayrı bir gösterilenle tamamlanan yeni bir gösterge olarak görür ve bu birleşim de yeni bir göstergeyi getirecektir. Anlatılan miti iç içe geçmiş göstergelerden oluşmuş bir bütün olarak resmetmektedir. Bu iki aşamalı süreçte bir düz anlam (denotation) bir de yan anlam (connotation) bulunmaktadır. Düz anlam, göstergenin olduğu gibi kavrandığı halidir. Yan anlamsa düz anlamın dışında ondan etkilenerek ortaya çıkmış yeni göstergesel ilişkidir. İletişimdeki alıcının iletiden çıarttığı altta yatan anlamlardır.

Roland Bathes'ın mitsel bir konuşma olarak gördüğü çeşitli mecralar konuşma dilinin yanı sıra her türlü fotoğraf, obje, tablo gibi görsel mecralar da olabilir. Bunlardan biri de afişlerdir. Barthes'ın, "mitsel" göstergebilim yaklaşımı çerçevesinde aşağıdaki afişler çözümlenmiştir. Bu afişlerde anlatılan mitler, afişte yer alan görsel ve yazınsal gösteren ve gösterilenlerin bir araya gelerek oluşturduğu göstergeleri içermektedir. İlk aşamada görsel algıya hitap eden göstergelerin, bağımsız formlarında ve bir araya geldiklerinde bütün oluşturacak şekilde hangi mesajları iletecekleri üzerinde durulmuştur. Bunun için; görsel ve yazınsal olarak ortaya konmuş "gösterenler" Barthes' ın yaklaşımına göre; "görüntü birimler", bu gösterenlere ait "gösterilenler" ise "içerik birimler"dir. Bu çalışmadaki göstergebilimsel çözümlemede, Hitler türü propaganda özellikleri öncelikle düz anlamları daha sonra yan anlamları olarak hangi iletileri ilettikleri çerçevesinde sorgulanmıştır. Sonuç olarak; anlam üretim alanı olan iletişim içerisindeki yerleri yapısal olarak incelenmiştir.

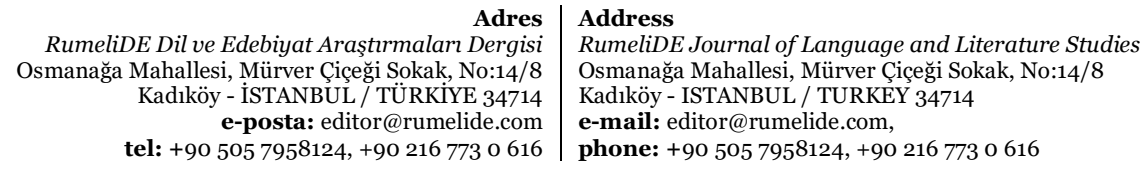




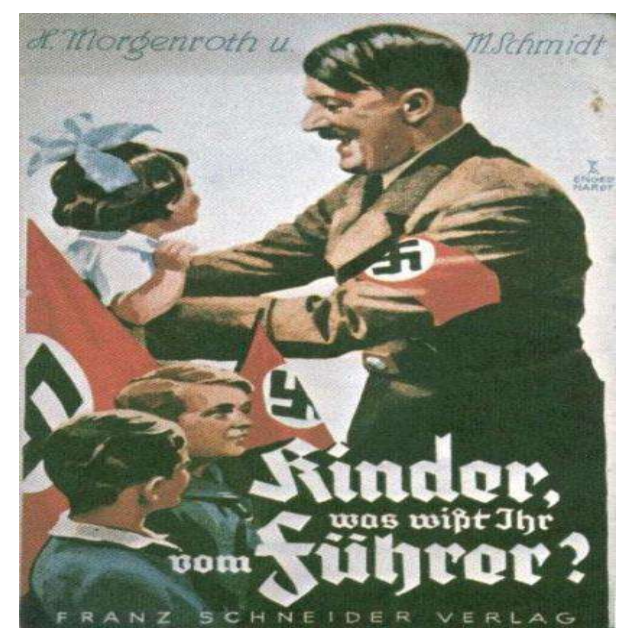

Kaynak: https://justonepaigeatatime.wordpress.com/2016/o1/16/propaganda-and-children/

\begin{tabular}{|c|c|c|}
\hline Gösteren & Gösterilen & \\
\hline & Düz Anlam & Yan anlam \\
\hline Hitler & Bir lider & $\begin{array}{l}\text { Nazi propagandasının } \\
\text { otoriter lideri }\end{array}$ \\
\hline Kiz çocuk & Yetişkin olmayan insan & $\begin{array}{l}\text { Duyguları yoğun, masum, } \\
\text { işlenmemiş çocuk hedef }\end{array}$ \\
\hline İki erkek öğrenci & $\begin{array}{l}\text { Öğrenim ve eğitim gören } \\
\text { erkek çocuklar }\end{array}$ & $\begin{array}{l}\text { Daha çok mantık eğilimli, } \\
\text { işlenmekte olan, ögrenim } \\
\text { gören fakat yine masum } \\
\text { çocuk hedef kitle }\end{array}$ \\
\hline Nazi bayrağı & Örgütün resmi aracı & $\begin{array}{l}\text { Teşkilatı ve propagandayı } \\
\text { önde tutan, coşku aracı }\end{array}$ \\
\hline Gamalı haç & Nazi sembolü & İyi, sağlıklı, mutlu olmak \\
\hline
\end{tabular}




\begin{tabular}{|l|l|l|}
\hline Kırmızı & Bir renk & $\begin{array}{l}\text { İştah, öfke, şiddet, coşku, } \\
\text { sicaklık, enerji, canlllı, } \\
\text { hareketlilik, güç, hırs } \\
\text { duyguları }\end{array}$ \\
\hline $\begin{array}{l}\text { Almanca “Çocuklar, Führer hakkına ne } \\
\text { biliyorsunuz?" yazısı }\end{array}$ & $\begin{array}{l}\text { Bir dilsel iletişim aracı } \\
\text { olan slogan }\end{array}$ & Harekete geçirici slogan \\
\hline
\end{tabular}

Hitler propagandasının en çok kullandığı araçlardan bir afiş örneğine bakıldığında amacına yönelik hangi yolu izlemeye çalıştığı açıklıkla görülebilir. Bu afişte kullanılan gösterenler (görüntü birimler) "Hitler”, "kız çocuk”, "iki erkek öğrenci”, "Nazi bayră̆ı”, "gamalı haç”, "kırmızı”, Almanca "Çocuklar, Führer hakkında ne biliyorsunuz?” yazısı olarak belirlenebilmektedir.

Gösterilenlere (içerik birimler), Hitler türü propagandanın amaçları açısından düz ve yan anlam olarak bağımsız bir şekilde ve birbirleri ile ilişkileri çerçevesinde bakıldığında, düz anlam olarak; "Hitler" bir lider, "kız çocuk" yetişkin olmayan insan, "erkek öğrenciler" öğrenim ve eğitim gören erkek çocuklar, "Nazi bayrağı" örgütün resmi aracı, "gamalı haç" Nazi sembolü, "kırmızı" bir renk, Almanca "Çocuklar, Führer hakkında ne biliyorsunuz?" yazısı bir dilsel iletişim aracı olan slogan olarak nitelendirilebilmektedir. Yan anlam olaraksa; "Hitler" Nazi propagandasının otoriter lideri, "kız çocuk" duyguları yoğun, masum, işlenmemiş hedef, "erkek öğrenciler” daha çok mantık eğilimli, işlenmekte olan, öğrenim gören fakat yine masum çocuk hedef kitle, "Nazi bayrağı” teşkilatı ve propagandayı önde tutan, coşku aracı "gamalı haç" iyi, sağlıklı, mutlu olmak (Gamal haç ismi Yunanca gama (Г) harfine ve haç şekline (+) atfen verilmiştir. Svastika kelimesi Sanskritçe'deki su (iyi) ve asti (olmak) kelimelerinin birleşiminden oluşmuştur), "kırmızı" iştah, öfke, şiddet, coşku, sıcaklık, enerji, canlılık, hareketlilik, güç, hırs duyguları, Almanca "Çocuklar, Führer hakkında ne biliyorsunuz?" harekete geçirici slogan olarak ayrıntılı bir biçimde incelenebilmektedir.

\section{2. "Hitler" Afişi}

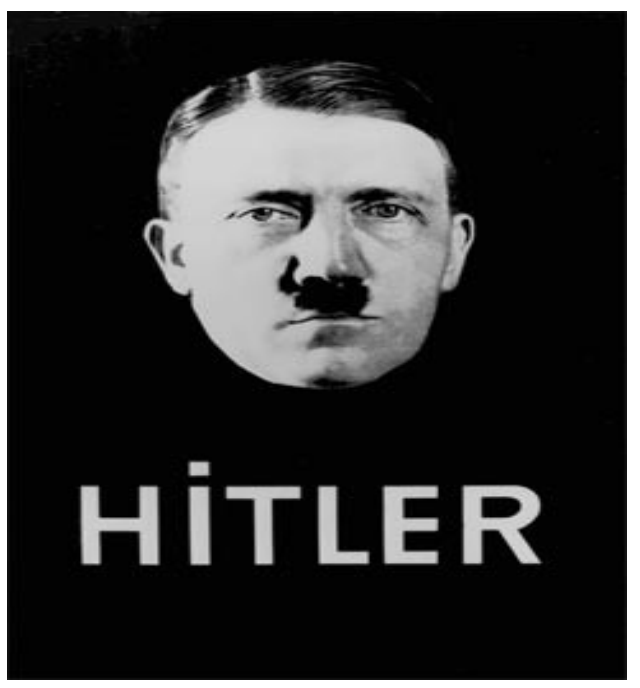

Kaynak: https://www.bbc.co.uk/history/worldwars/wwtwo/nazi_propaganda_gallery_o1.shtml

RumeliDE Dil ve Edebiyat Araştırmalar Dergisi $\quad$ RumeliDE Journal of Language and Literature Studies Osmanağa Mahallesi, Mürver Çiçeği Sokak, No:14/8 $\quad$ Osmanağa Mahallesi, Mürver Çiçeği Sokak, No:14/8 Kadıköy - ISTANBUL / TÜRKIYE 34714 Kadıköy - ISTANBUL / TURKEY 34714 e-posta: editor@rumelide.com e-mail: editor@rumelide.com, tel: +90 505 7958124, +90 2167730616 phone: +90 505 7958124, +90 2167730616 


\begin{tabular}{|l|l|l|}
\hline Gösteren & Gösterilen \\
\hline Siyah & Düz Anlam & Yan anlam \\
\hline Beyaz & Bir renk & $\begin{array}{l}\text { Belirsizlik, karanlık, } \\
\text { asalet }\end{array}$ \\
\hline Hitler başı & Bir beyaz & $\begin{array}{l}\text { Yenilik, saflık, temizlik, } \\
\text { gençlik, umut çocuk hedef }\end{array}$ \\
\hline "HíTLER" yazısı & Bir liderin başı & $\begin{array}{l}\text { Liderin baş oluşu, önde } \\
\text { gelişi, karanlığa } \\
\text { başkaldırışı ve doğuşu }\end{array}$ \\
\hline
\end{tabular}

Bu afişteki gösterenlere (görüntü birimler) gelince; "siyah”, "beyaz”, "Hitler başı", "Hitler yazısı" sunulmaktadır. Bunların Hitler türü propaganda açısından gösterilenlerine bakmak gerekirse, gösterilenler (içerikbirim) düz anlam olarak; "siyah" bir renk, "beyaz" bir renk, "Hitler başı" bir liderin başı, "Hitler yazısı" bir liderin isminin yazılışı olarak öne çıkmaktadır. Yan anlamlar ise; "siyah" belirsizlik, karanlık, asalet, "beyaz" yenilik, saflık, temizlik, gençlik, umut, "Hitler başı” liderin baş oluşu, önde gelişi, karanlığa başkaldırışı ve doğuşu, "Hitler yazısı” yalnız ve tek Hitler, liderin ön planda oluşu anlamları ile kodlanmaktadır.

\section{Sonuç ve tartışma}

$\mathrm{Bu}$ çalışmada, siyasal propaganda türü olarak geçmişten bugüne yalnızca siyaset arenasında değil toplumsal alanlarda güç ve otorite kurmak adına sıklıkla başvurulan Hitler türü propaganda incelenmek istenmiştir. Hitler'in bir sanat olarak gördüğü propagandanın sembolik açıdan zengin sanatsal olarak adlandırılabilecek afişler ile yaratacağı etki göz önünde bulundurularak göstergeler tek tek ve bütüncül bir yaklaşımla incelenmesi amaçlanmıştır. Afişler, iletişimin kökeninin dayandığı dile yapısalcı kuram çerçevesinde iletilerin anlam dolu metinler olması anlayışıyla göstergebilimsel analiz ile incelenmiştir. Kavramsal çerçevede sunulan propaganda uygulama kurallarından hangilerinin bu afişlerde uygulandığı betimlenmiştir. Afişlerde bulunan göstergeler, göstergebilim öncülerinden Roland Barthes'ın düz anlam ve yan anlam temellendirmesiyle analiz edilmiştir.

Buna göre, Hitler türü propagandanın temsil edildiği iki adet afiş incelenmiştir. "Çocuklar, Führer hakkında ne biliyorsunuz?” adlı afişte sunulan, tüm gösteren ve gösterilen ilişkisi içinde kullanılan göstergelerden çıkarılabilecek sonuçlara bakıldığında; Hitler' in halkın çoğunluğunu duyguları temsil eden kadınla özdeşleştirme felsefesine uyduğu görülmektedir. Halkın içinde kucaklayıp yukarı kaldırdığ kız çocuk halkı temsil etmektedir. "Sağlıklı, verimli” Hitler' in "ari ırk" hedefine uygun bu kız çocuğunu işlenmesi daha zor olduğu düşünülen erkek öğrencilerin arasından çıkarmaktadır. Eğitim sürecinde olan erkek çocuklardansa ona göre inandırması daha kolay olan kız çocuk halkı temsil etmekte ve Hitler'in hedef kitlesini sembolize etmektedir. Öte yandan bu kız çocuğu tekleştirmesi "seçme" kuralına uygundur.

"Hitler" adlı ikinci afişte ise telkin ve tekrarın Hitler propagandasında başarıyla kullanıldığı söylenebilmektedir. Direkt olarak bu afiş üzerinde bir analiz yapılmak istendiğinde ilk başta söylenebilecek şeyin "aşırı basitleştirme" tekniğine başvurulduğudur. Odak noktasının yalnızca ve yalnızca Hitler olduğu görülmektedir. Siyah-beyaz renklerdeki Hitler’ in görüntüsü ki burada yalnızca baş bölgesi kullanılmaktadır. Hitler yazısından başka bir gösterge kullanılmamış, bir propaganda tekniği

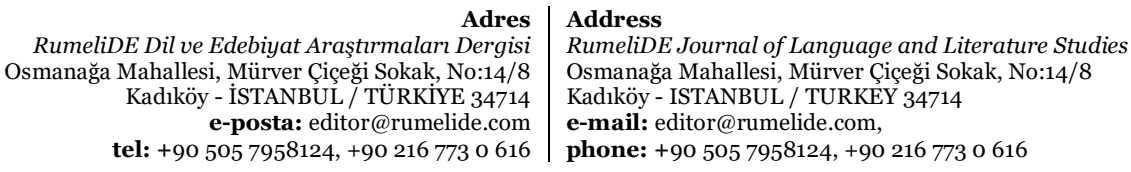


olarak "sadeleştirme ve teke indirme" yoluyla bir afiş hazırlanmıştır. Lider karanlıktan bembeyaz bir şekilde umut verici, yenilikçi, "ari" biçimde çıkagelmektedir. Artık halk için yalnızca tek bir seçenek sunulmaktadır: O da HITTLER'dir.

Hareketli reklamlar, belgeseller, kısa filmler dışında ses imgesi kullanılmadan istenilen amaca uyulabilecek bir başka propaganda mecrası olarak afişlerde de Hitler türü propagandanın sistematik ve bilinçli bir şekilde kullanıldığı bu çalışmanın ortaya koyduğu temel sonuçtur. Araştırma soru ve alt problemler detaylı şekilde göstergebilimsel analiz ile cevaplandırılmıştır.

\section{Sinurlılıklar ve öneriler}

$\mathrm{Bu}$ çalışma, ses imgelerinden arınmış tamamen görsel iletişime dayalı bir göstergebilimsel analiz yapmak adına afiş mecrası ile sınırlandırılmıştır. Ayrıca bir başka sınırlılıksa, siyasal propaganda uygulayan farklı dünya liderlerinin içinden seçilen Adolf Hitler’in propaganda tekniğidir. Gelecek araştırmacılara, bu yönde farklı dünya liderlerinin uyguladığı siyasal propaganda türlerini düz anlam ve yan anlam temelinde bir göstergebilimsel analizle çalışmaları tavsiye edilmektedir.

\section{Kaynakça}

Alyakut, Ö. (2017). Postmodern toplumda değişen evler: yeni yaşam tarzı vadeden ev reklamlarmın göstergebilimsel incelemesi. İletişim Kuram ve Araş̧ırma Dergisi, 44, 244-263.

Barthes, R. (1993). Göstergebilimsel Serüven. (Çev. Rifat, M. ve Rifat, S.). İstanbul: Yapı Kredi Yayınları.

Barthes, R. (2004). Mythologies. (Eds: July Rivkin ve Michale Ryan). Literary Theory: An Anthology. (2ns Edition). Blackwell Publishing.

Bektaş, A. (2002). Siyasal Propaganda. İstanbul: Bağlam Yayınları.

Brown, J.A.C. (1992). Siyasal Propaganda. (Çev. Yazar, Y.). İstanbul: Ağaç Yayıncılık.

Domenach, J.M. (1995). Politika ve Propaganda. (Çev. Yücel, T.). İstanbul: Varlık Yayınları.

Eke, E. (2008). Siyasal propaganda araçlarının seçmen davranıșı üzerindeki etkisi: ısparta örnek olayı. Yayımlanmamış Yüksek Lisans Tezi, Süleyman Demirel Üniversitesi, Isparta.

Guiraud. P. (1990). Göstergebilim. Ankara: İmge Kitabevi.

Hitler, A. (2011),.Kavgam. İstanbul: Mola Kitap

Kalender, A. (2005). Siyasal İletisim. Çizgi Kitabevi.

Kongar, E. (2021). http://www.kongar.org/makaleler/mak_na.php

Lerner, D. (200o). Propagandada Etkinlik: Şartlar ve Değerlendirme. (Çev: Oskay, Ü. Kitle Haberleşmesi Teorilerine Giriş. Der: Oskay, Ü.). İstanbul: Der Yayınları.

Mazıcı, E. T. (2018). Adlf Hitler’in korku çekiciliği bağlamında kamu spotu reklamlarında kullanımı. Erciyes İletişim Dergisi, 5 (3), 290-306.

Özsoy, O. (1998). Propaganda ve Kamuoyu Olusturma. İstanbul: Alfa Kitabevi.

Rifat. M. (1998). XX. Yüzyılda Dilbilim ve Göstergebilim Kuramları: 1. Tarihçe ve Eleştirel Düşüncüler. İstanbul: Yapı Kredi Yayınları.

Saussure. F. (1983). Course in General Linguistics. (Ed. Bally, C. ve Sechehaye, A.). (Çev. Harris, R.). Illionis: Open Court. (özgün çalışma 1916)

Saussure. F. (2004). Course in general linguistics.(Eds: July Rivkin ve Michale Ryan). Literary Theory: An Anthology. (2ns Edition). Blackwell Publishing.

Teker. U. (2003). Grafik Tasarm ve Reklam. İzmir: Dokuz Eylül Yayıncılık.

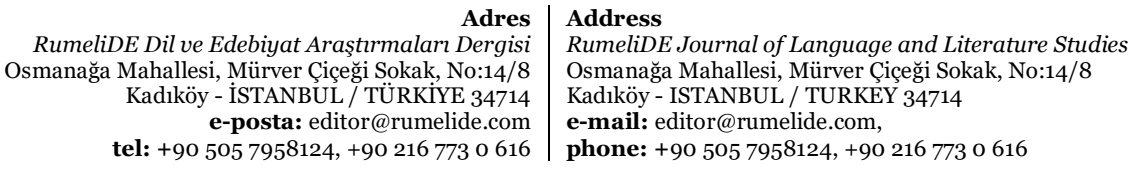


428 / RumeliDE Journal of Language and Literature Studies 2021.25 (December)

A semiological analysis on the use of Hitler propaganda in posters / H. D. Karcı (pp. 415-428)

Yılmaz, H. (2007). Michel Foucault'nun biyo-iktidar kavramı çerçevesinde nazi dönemi propaganda belgelerinin analizi. Yayımlanmamış Yüksek Lisans Tezi, Afyon Kocatepe Üniversitesi, Afyon. 